Omkar Editor

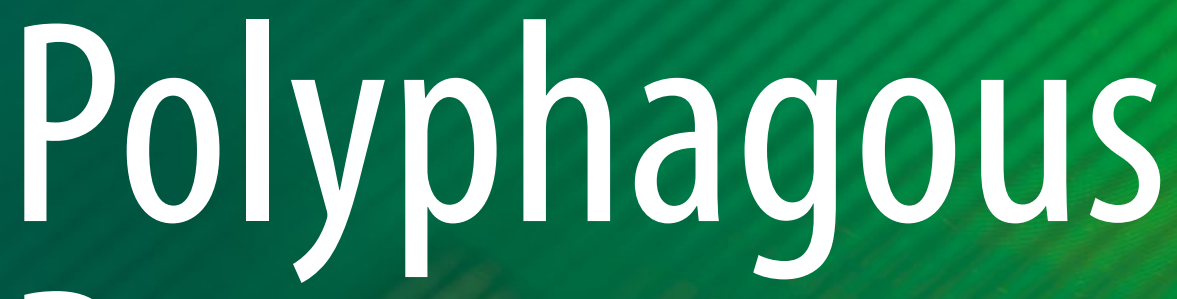

Pests

of crops

Springer 


\title{
Fall Armyworm (Spodoptera frugiperda)
}

\author{
Sharanabasappa S. Deshmukh, B. M. Prasanna, \\ C. M. Kalleshwaraswamy, Jagdish Jaba, and Bhagirath Choudhary
}

\section{Contents}

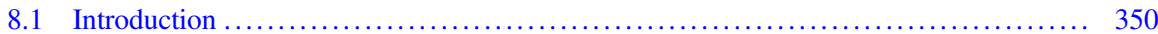

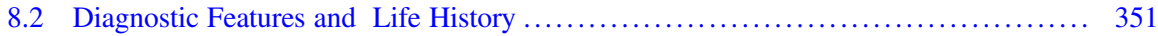

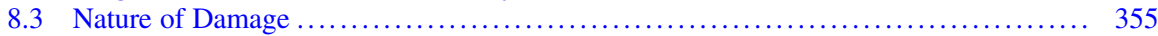

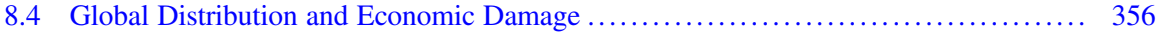

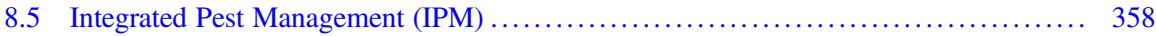

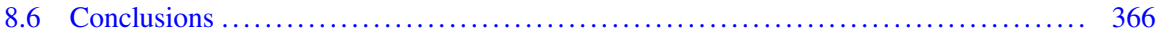

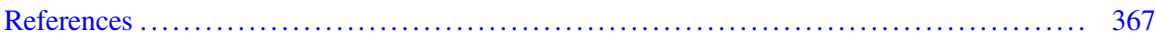

\section{Abstract}

The fall armyworm (FAW), Spodoptera frugiperda (J. E. Smith) (Lepidoptera: Noctuidae), originated from America but is reported recently from Africa and the Asia-Pacific. FAW has caused huge international concern since its outbreak in Africa since 2016 and in Asia since mid-2018. The chapter mainly reviews its

S. S. Deshmukh $(\varangle) \cdot$ C. M. Kalleshwaraswamy

Department of Entomology, College of Agriculture, University of Agricultural and Horticultural Sciences, Shivamogga, Karnataka, India

B. M. Prasanna

International Maize and Wheat Improvement Centre (CIMMYT), Nairobi, Kenya e-mail: b.m.prasanna@cgiar.org

J. Jaba International Crops Research Institute for the Semi-Arid Tropics (ICRISAT), Hyderabad, Telangana, India e-mail: jagdish@cgiar.org

B. Choudhary

South Asia Biotechnology Centre (SABC), New Delhi, India e-mail: bhagirath@sabc.asia

(C) The Author(s), under exclusive license to Springer Nature Singapore Pte

Ltd. 2021

Omkar (ed.), Polyphagous Pests of Crops,

https://doi.org/10.1007/978-981-15-8075-8_8 
global distribution, life cycle, identification characters, strains, host plants, nature of damage, economic damage, and integrated pest management strategies available. The pest completes its life cycle on maize in 30 days (in warm summer months); in cooler temperatures, it may extend up to 60-90 days. For effective management of fall armyworm, different tools, viz., cultural control, agronomic management, breeding for resistance, natural enemies, and eco-friendly insecticides, should be used in an integrated approach. As the insect is recently introduced to Africa and the Asia-Pacific, possible management strategies and future cases of action are discussed.

\section{Keywords}

Fall armyworm $\cdot$ Life history $\cdot$ Nature of damage $\cdot$ Natural enemies $\cdot$ Management

\subsection{Introduction}

Invasive species are the biggest threat to the environment and cause ecological and economic losses (Wilson 1992; Evans et al. 2016). In the United States alone, invasive species have estimated to cause US\$120 billion loss annually (Pimentel et al. 2005). The fall armyworm (FAW), Spodoptera frugiperda (J. E. Smith) (Lepidoptera: Noctuidae), originated from the Americas (Luginbill 1928; Sparks 1979) with wide host plants that include maize, sorghum, millets, rice, sugarcane, soybean, vegetables, and cotton (Prowell et al. 2004; Bueno et al. 2010; Padhee and Prasanna 2019). Fall armyworm is highly migratory in nature and has high fecundity, wide range of host plants, and voracious feeding behavior, without diapause. These characteristics make the fall armyworm a major destructive crop insect pests. Due to variation in weather conditions in the Americas, seasonal and continental movement of this pest from Canada to Argentina is noticed (Mitchell et al. 1991; Nagoshi and Meagher 2004, 2008). In eastern region of the United States, moth migration from the northeast to the southeast was noticed annually (Nagoshi et al. 2017).

Outside the Americas, FAW was first reported in West Africa in January 2016 (Goergen et al. 2016) and has spread to more than 40 countries across Africa (Prasanna et al. 2018a). In May 2018, this highly invasive insect pest was noticed for the first time in India on the maize crop in the Shivamogga and Davanagere districts and Karnataka state (Sharanabasappa et al. 2018a) and subsequently reported by Ganiger et al. (2018) and Shylesha et al. (2018). 


\subsection{Diagnostic Features and Life History}

\subsubsection{Diagnostic Features}

The later instar larvae (fourth to the sixth instars) are brownish black with three white dorsal lines and alight lateral line. On the dorsal side of the larva, black tubercles are found which bear spines. The frons has white inverted "Y" line on the head, and four dark warts in a square form on the dorsal surface of the eighth abdominal segment (Fig. 8.1) (Prasanna et al. 2018a). Forewing of male is gray brown with white triangular patch at the apical region and circular spot at the center of the wing (Fig. 8.2e), whereas female has uniformly grayish brown forewings mottled with dark brown spots (Fig. 8.2f). The hindwings of both male and female are silvery white with a dark border (Oliver and Chapin 1981; Prasanna et al. 2018a; Sharanabasappa et al. 2018b; Ganiger et al. 2018).

As there is no diapause reported in this pest, overlapping generations are noticed in a cropping period (Sharanabasappa et al. 2020a), the same as in Africa where continuous host plants are available in off-season irrigated crops (Prasanna et al. 2018a). However, in America, where cooler climate exists, fall armyworm cannot survive; hence, it migrates to warmer regions in the winter months. Under tropical climates of Asia and Africa, where there is a bimodal pattern of rainfall, pest may thrive throughout the year causing economic losses.

Although both vegetative and reproductive parts are damaged by the fall armyworm, feeding injury results in whitish patches and ragged and elongated holes. Increased feeding further in the whorl may even affect the development of tassel. Extensive leaf damage due to $S$. frugiperda may significantly reduce the photosynthetic area, which may result in stunted plants and reduction in grain yield. At the reproductive stage, the larvae may bore through the side or top of the earhead and start feeding on kernels at milky stage, affecting the quality of the grain and yield.

\subsubsection{Life History}

Fall armyworm takes about 30 days to complete its life cycle on maize in warm summer months; however, in cooler temperatures, it may extend up to 60-90 days (Prasanna et al. 2018a). Detailed information on various stages of the pest is presented below.

\subsubsection{Egg}

The female adult lays about 1000 eggs in clusters on below or above the leaf surface of the maize plant, at the base of the plant, and also in whorls. The eggs are ventrally flattened. Immediately after laying, the eggs are of light green in color (Fig. 8.2a) for a day and then turn to golden yellowish and finally to black color before hatching. The female covers a layer of scales on the egg mass with moldy appearance. Egg hatching may take from 2 to 3 days with an average of 2.50 days (Prasanna et al. 2018a; Sharanabasappa et al. 2018b). 
a

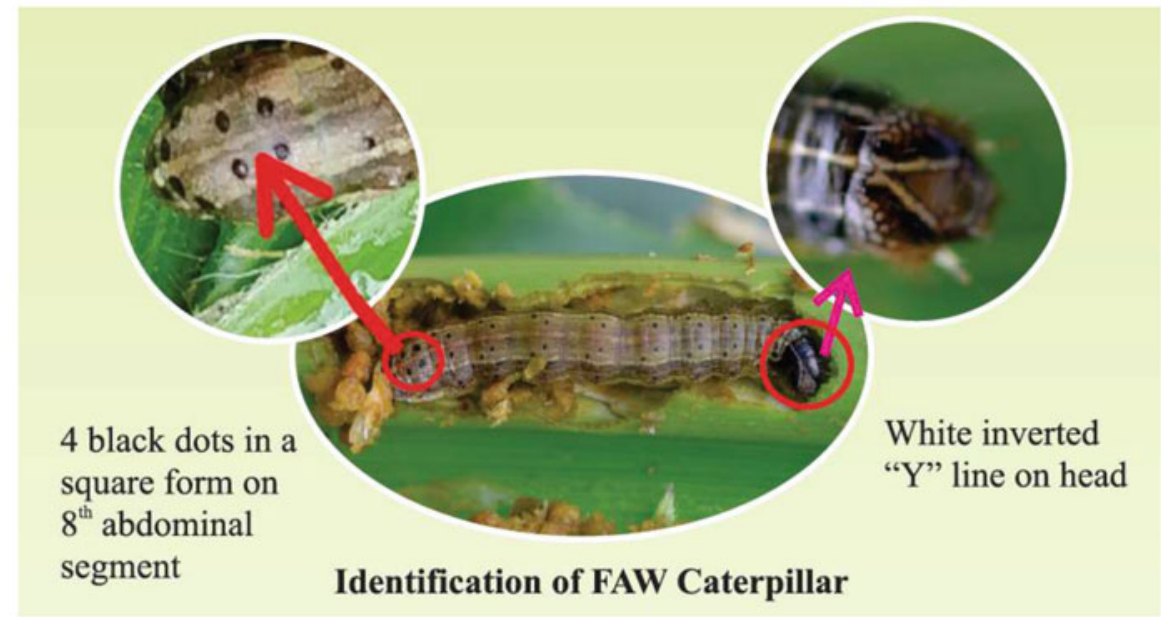

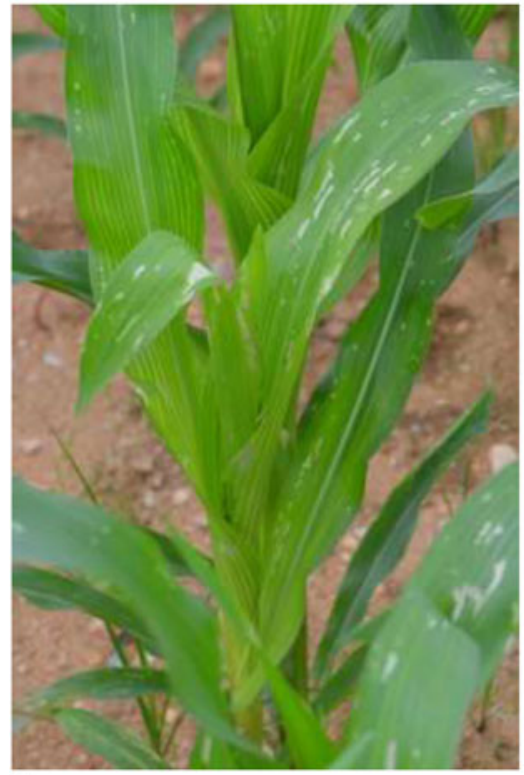

b

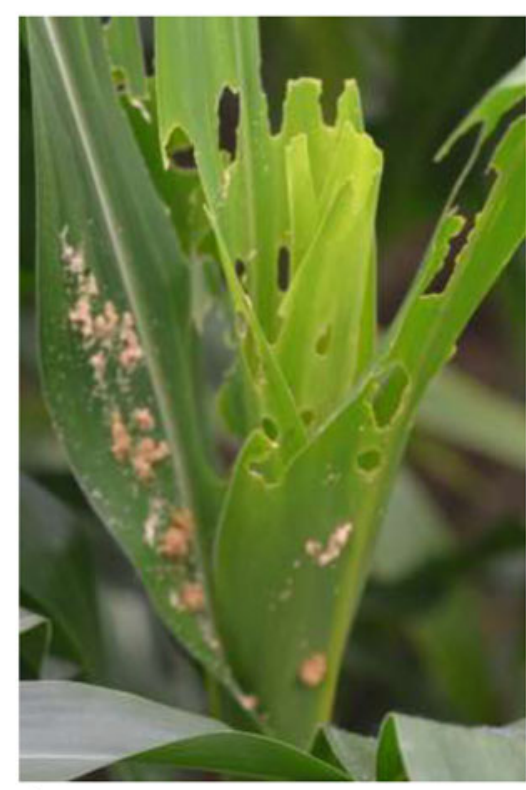

c

Fig. 8.1 (a) Identification of fall armyworm caterpillar (Photos: Sharanabasappa) (b) Scratches on the upper surface of the leaf due to feeding of the early instar larvae (c) Sawdustlike faecal matter found within the whorl and on upper leaves due to later instar larva

\subsubsection{Larva}

There are six larval instars with 14-19 days of larval duration, and color changes from instar to instar. First instars are green with a black head but it turns greenish 


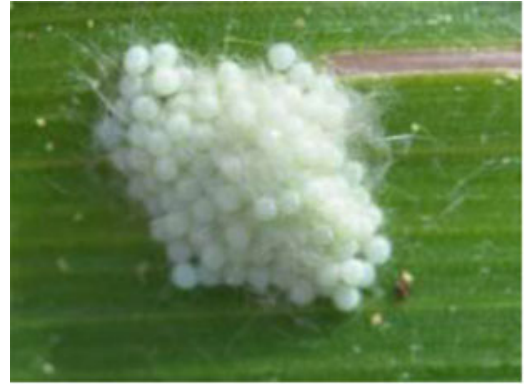

(a)

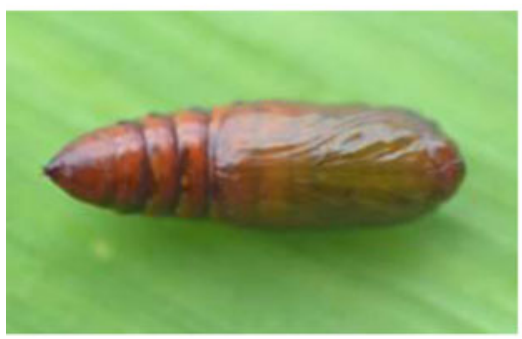

(c)

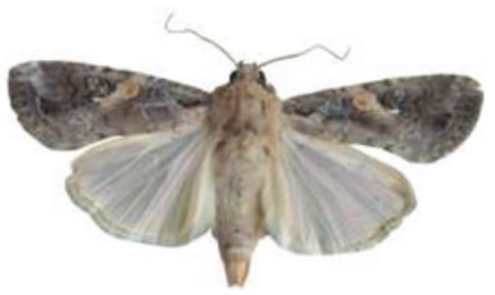

(e)

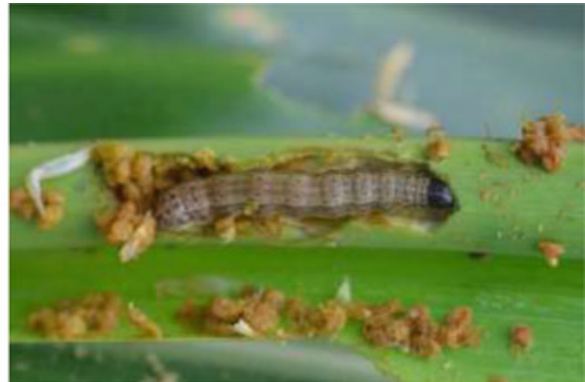

(b)

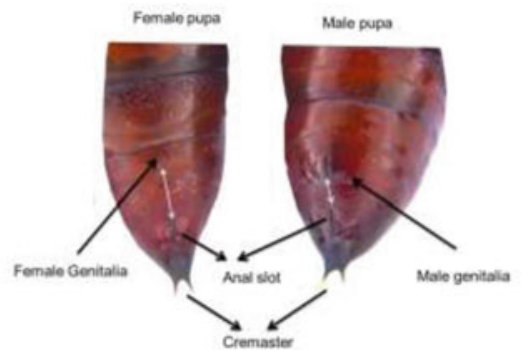

(d)

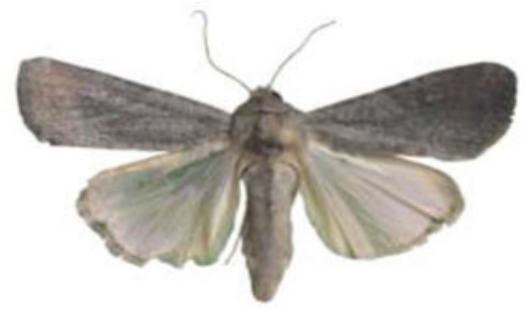

(f)

Fig. 8.2 Life stages of fall armyworm (a) Egg mass (b) Larva (c) Pupa (d) Pupal sexing in female and male (e) Adult Male (f) Adult Female. (Photos : Sharanabasppa)

brown during second instar. From third instar onward, larvae turn brown with three dorsal and lateral white lines (Fig. 8.2b) (Prasanna et al. 2018a; Sharanabasappa et al. 2019b, ICAR - IIMR 2019).

\subsubsection{Pupa}

Pre-pupa stops feeding and turns bright brown during pupal stages (Fig. 8.2c). Pupation takes place in the soil, and pupal period ranges from 9 to 12 days (Prasanna et al. 2018a; Sharanabasappa et al. 2019b). Pupal sexing can be done by looking at the genital opening. The distance from the genital opening to the anal slot can be 
used to distinguish the female and male pupa. The distance from the genital opening to the anal slot is more in female pupa than in the male pupa (Fig. 8.2d).

\subsubsection{Adult}

The adult longevity includes preoviposition, oviposition and post-oviposition periods ranged from 3 to 4,2 to 3 , and 4 to 5 days, respectively. In captivity, each female lays 835 to 1169 eggs with an average of about 1000 eggs. The total life cycle of male and female fall armyworm ranges from 32 to 43 and 34 to 46 days, respectively (Sharanabasappa et al. 2018b).

The female survives for 10.80 days with a range of 9-12 days compared to the male (8.20 days) with a range of 7-9 days. The average wingspan of female is $3.20 \mathrm{~cm}$ with a range of 3.00 to $3.4 \mathrm{~cm}$, while it is $3.25 \mathrm{~cm}$ with a range of 3.00 to $3.50 \mathrm{~cm}$ in male (Sharanabasappa et al. 2018b).

Temperature and developmental rate of fall armyworm are linearly related between $18^{\circ} \mathrm{C}$ and $30^{\circ} \mathrm{C}$ and $26^{\circ} \mathrm{C}$ and $30^{\circ} \mathrm{C}$, respectively. Studies demonstrated that $26^{\circ} \mathrm{C}$ and $30^{\circ} \mathrm{C}$ are the optimal range for egg, larval, and egg-to-adult development and lower larval maturity and the optimum temperature with the fastest larval development rate, and lowest mortality was at $30^{\circ} \mathrm{C}$ as reported by Du Plessis et al. (2020) (Table 8.1).

\subsubsection{Strains of Fall Armyworm}

FAW has two strains that are morphologically similar but differ in their host plant preference. The rice strain (R-strain) prefers to feed on rice, Bermuda grass, and other small grasses, whereas the corn strain (C-strain) prefers to feed on maize, sorghum, and other large grasses (Pashley et al. 1985; Pashley 1986; Pashley et al. 1987). These two strains do not have any clear biological attributes even though differences are evident in the whole genome, transcriptome, etc. (Gouin et al. 2017; Silva-Brandao et al. 2017). Mahadevaswamy et al. (2018) reported the presence of $\mathrm{R}$-strain in population sampled from different parts of India using mtCOI gene, but this requires further validation. Maruthadurai and Ramesh (2020) reported the R-strain in the FAW population from Goa. It must be noted that the FAW population

Table 8.1 Duration of different life stages of FAW at different temperature regimes

\begin{tabular}{l|l|l|l|l|l}
\hline \multirow{2}{*}{ Development stage } & \multicolumn{5}{l}{ Temperatures $\left( \pm 1^{\circ} \mathrm{C}\right)$} \\
\cline { 2 - 6 } & 18 & 22 & 26 & 30 & 32 \\
\hline Egg (days) & $6-7$ & 4 & 3 & 2 & 2 \\
\hline Laval duration (days) & $28-37$ & $19-22$ & $13-19$ & $10-14$ & $10-12$ \\
\hline Pupal duration (days) & $28-34$ & $14-20$ & $10-13$ & $8-10$ & $7-9$ \\
\hline Egg to adult (days) & $66-77$ & $38-46$ & $27-32$ & $20-25$ & $19-22$ \\
\hline Larval mortality (\%) & 71 & 37 & 15 & 4 & 28 \\
\hline
\end{tabular}

Source: Du Plessis et al. (2020) 
in India preferentially damages maize, sorghum, and millets than rice. Hence, there is a confusion how mtCOI-detected R-strain is preferring to feed on rice in India.

In the Americas, the commonly used markers to identify morphologically indistinguishable $\mathrm{C}$-strain and $\mathrm{R}$-strain populations are mitochondrial cytochrome oxidase subunit I (COI) and nuclear triosephosphate isomerase (Tpi). Fall armyworm has two strains collections from Africa and India were reported to be R-strain detected by COI marker, although collections tested to date are from C-strainpreferred crops. When Tpi marker was used, $>95 \%$ of the specimens were identified as C-strain. This indicates that Tpi marker is the ideal marker for identification of strains in Asian population. However, the presence of the R-strain in the Eastern Hemisphere needs constant watch, as it prefers to attack major host such as rice (Nagoshi et al. 2020).

The studies also suggest that fall armyworm from Africa and Asia has genetic similarity indicating invasion occurred from small number of population from the Western Hemisphere. The confusion of R-strain $\times \mathrm{C}$-strain might be due to interstrain mating (Nagoshi et al. 2020).

Genetic evidence also suggests that FAW from Africa, India, Myanmar, and China shows that populations share a common and recent origin that derived from a small number of introductions (as few as one) from the Western Hemisphere. Nagoshi et al. (2020) provided two lines of evidence that suggest that a single strain predominates in the Eastern Hemisphere and that it is most likely the C-strain. Overall, they suggested that the FAW from Africa is behaving as expected for the $\mathrm{C}$-strain, with the R-strain a minor presence or perhaps even absent. They also suggested that in Myanmar, China, India, and most of Africa, the COI strain marker is in disagreement with both Tpi and host plant. One way this could have occurred might be linkage between the mitochondrial $\mathrm{COI}$ marker and strain identity that was disrupted by inter-strain mating. Since mitochondria are maternally inherited, mating between an R-strain female and C-strain male would produce COI-RS hybrid daughters, which if they also mated with $\mathrm{C}$-strain males would produce COI-RS progeny in a C-strain (including TpiC) background (Nagoshi et al. 2020).

Hybrid daughters may be produced with COI-RS strain male mates, as the mitochondria are maternally inherited. There is a need for comprehensive genetic analysis for invasive population to understand the strains and the host plants attacked. However, recent studies (Nagoshi et al. 2019, 2020) suggest the need for more extensive sampling of FAW on many more host plants across Asia for more reliable detection of host-associated differences.

\subsection{Nature of Damage}

Fall armyworm moths are nocturnal and hide during the daytime in the whorls of the maize plant. They are more active during the evening hours. Female moth lays eggs above/below the leaf surface of the maize plant, at the base of the plant, and also in whorls. Immediately after hatching, the neonate larvae secrete a silken thread and spread to the neighboring plants through wind. Early instars (1-3 instar stages) feed 
on the leaves, causing whitish patches appearing as "scratches" on the leaf surface (Fig. 8.1b). Grown-up caterpillars feed on leaf tissues resulting in ragged and elongated holes on leaves leading to sickly appearance. A very diagnosable symptom of attack is the presence of lumps of fecal matter in the whorls (Fig. 8.1c). Fall armyworm incidence starts when the crop is around 10-20 days after sowing. In early stage of the crop, 2-3 larvae are noticed feeding on the leaves, and in later stage of the crop, one or two later instar larvae per plant are noticed when the crop is around 30 to 40 days old. When two larvae are found in a single whorl, their feeding sites are different because in fall armyworm cannibalism is noticed. The early instar enters the cob through silk, whereas the later instar larva bores the husk and goes inside the cob and feeds on the kernels (Fig. 8.3a).

\subsection{Global Distribution and Economic Damage}

FAW has been found in 43 countries of Africa, 41countries in North America, 28 countries in Central America, and 32 countries in South America (Dively 2018). The pest is now widely prevalent in the Asia-Pacific region, including India, Yemen, Bangladesh, Sri Lanka, Thailand, Myanmar, China, Indonesia, Laos, Malaysia, Vietnam, Republic of Korea, Japan (FAO 2019), Nepal (Bajracharya et al. 2019), Indonesia (CABI 2019), and the Philippines (Navasero et al. 2019). Now the presence of this pest is reported in all states of India, except for a few northern states (Rakshit et al. 2019). Fall armyworm has spread to 26 provinces of China, the second biggest maize-producing country in the world after United States (Jiang et al. 2019). Recently, in February 2020, the pest has been reported in Australia (FAO 2020a; QGDAF 2020).

FAW is a highly invasive insect pest, with adult moth dispersal strongly influenced by wind and environmental conditions. FAW moths were reported to travel more than $100 \mathrm{~km}$ per day and nearly $500 \mathrm{~km}$ before egg laying, and they can move to newer places very quickly under favorable wind conditions. FAW is highly polyphagous; Montezano et al. (2018) reported a host range of 353 plant species from 76 plant families, principally Poaceae (106), Asteraceae (31), and Fabaceae (31). Despite such a broad host range, maize is undoubtedly the most widely preferred host by the pest. In Africa as well as in Asia, FAW damage has been mostly reported on maize, followed by a few other crops, like sorghum, millets, and vegetables. FAW has not adversely affected rice, despite its extensive cultivation in West Africa and many other sub-Saharan Africa countries (Rwomushana et al. 2018).

Yield losses due to FAW were estimated around $40 \%$ in Honduras in Central America (Wyckhuys and O’Neil 2006) and $72 \%$ in Argentina (Murúa et al. 2006). According to FAO, Brazil alone spends US\$600 million annually on FAW management (Wild 2017). Abrahams et al. (2017) reported that FAW has the huge potential to cause $21 \%$ to $53 \%$ reduction in annual maize production (or US\$2,481 to US $\$ 6,187$ million economic damage) in 12 maize-producing African countries. In Africa, the maize losses were estimated at US\$2.5 to 6 million due to fall armyworm in 2017 (Day et al. 2017). 
Fig. 8.3 (a) Fall armyworm feeding on cob (Photos:

Sharanabasappa) (b) Maiza

(c) Sorghum (d) Pearl millet (Phot: Jaba J) (e) Sugarcane

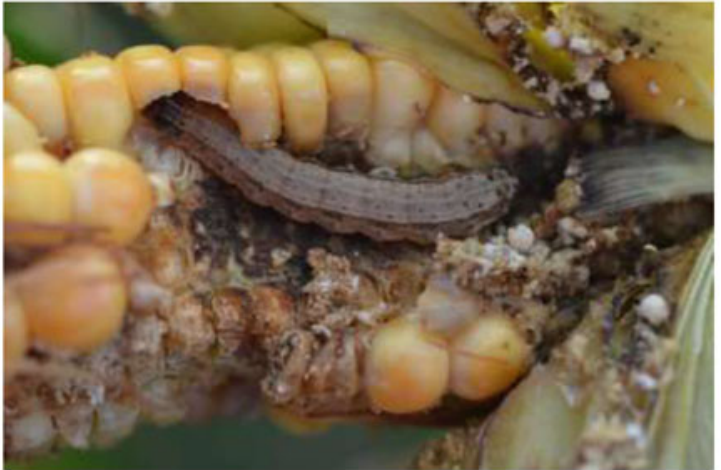

a

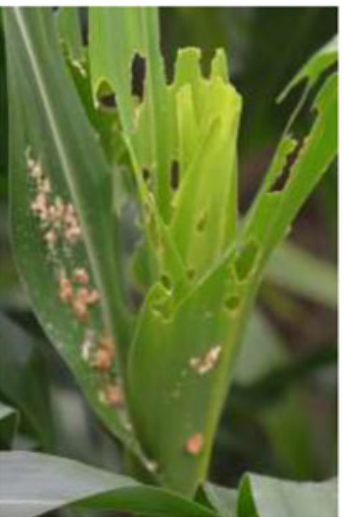

b

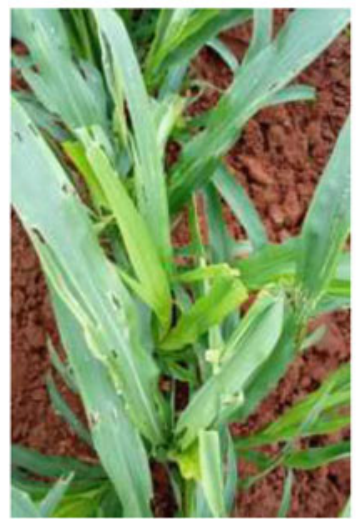

d

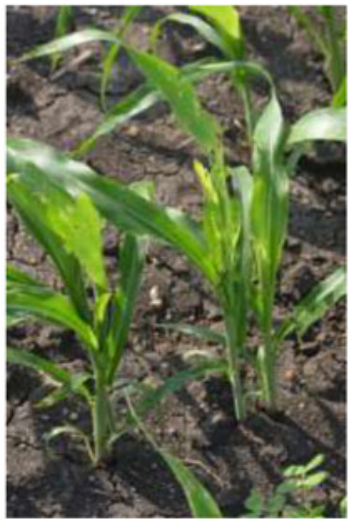

c

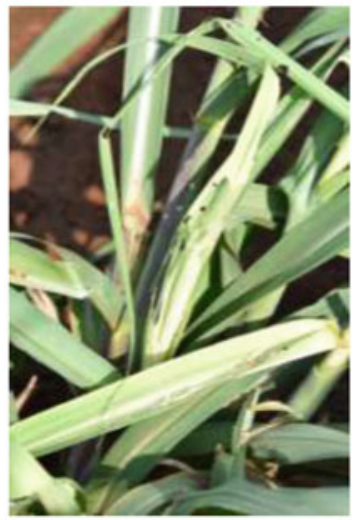

e 


\subsubsection{Crop Damage in India}

Maize is the third most important cereal crop after rice and wheat, both in terms of area and production, registering maximum growth rate among food crops. In India, maize is grown in an area of 9.2 million hectares with a production of 27.82 million metric tonnes per year (FAO 2018). As reported by DMR (2012) and Chaudhary et al. (2012), the utilization pattern for maize in India includes mainly poultry feed $(52 \%)$, human food $(24 \%)$, animal feed $(11 \%)$, and industrial processing $(12 \%)$. The maize area affected due to fall armyworm in India in 2018-2019 was reported to be about 2.45 lakh hectares (Anonymous 2019). In India, it primarily feeds on maize (Fig. 8.3b), fodder maize, sweet corn, baby corn, and also other hosts, like sorghum (Fig. 8.3c), pearl millet (Fig. 8.3d), finger millet, sugar beet, and grasses, as reported by different workers (Table 8.2). In addition, FAW feeding was also reported on sugarcane (Fig. 8.3e) (Chormule et al. 2019) but not causing significant yield loss.

\subsection{Integrated Pest Management (IPM)}

The aim of IPM is to economically reduce the pest populations using suitable techniques and methods that minimize hazard to the environment, including people. IPM requires the farmers or farm advisors to have significant knowledge of agronomic and pest management approaches to implement an effective program based on local farming conditions (Prasanna et al. 2018a). The experiences so far in the Americas as well as Africa clearly show that there is no specific solution or magic bullet for effectively and sustainably controlling FAW. An IPM strategy based on science, inclusiveness, and balanced strategy is the need of the hour (Fig. 8.1). Emergency responses exclusively based on the use of synthetic pesticides have shown satisfactory results but need to be economically viable, to be used as per label claims, and must be safe for human health, biodiversity, and the environment (Fig. 8.4).

An effective IPM strategy for control of FAW will employ a toolbox approach, with different tools used in combination based on the cropping system, availability of technologies, and socioeconomic conditions of the farming communities. The IPM toolbox for FAW management could potentially include cultural control, agronomic management, host plant resistance, biological control, and environmentally safe synthetic biopesticides to protect the crops from economic injury while minimizing negative impacts on people, animals, and the environment (Prasanna et al. 2018a).

\subsubsection{Monitoring, Surveillance, and Early Warning}

Tracking and monitoring the spread of FAW across the country, region, and continent in a timely manner are critical if good decisions relating to control and management are to be made. Standard methodologies for field scouting and 
Table 8.2 Host range of fall armyworm in India

\begin{tabular}{|c|c|c|c|c|}
\hline S. no & Family & $\begin{array}{l}\text { Scientific } \\
\text { name }\end{array}$ & $\begin{array}{l}\text { Common } \\
\text { name }\end{array}$ & References \\
\hline 1 & Poaceae & Zea mays $\mathrm{L}$. & Maize & $\begin{array}{l}\text { Sharanabasappa et al. (2018a), } \\
\text { Ganiger et al. (2018), and Shylesha } \\
\text { et al. (2018) }\end{array}$ \\
\hline 2 & Poaceae & Zea mays $\mathrm{L}$ & $\begin{array}{l}\text { Fodder } \\
\text { maize }\end{array}$ & Maruthadurai and Ramesh (2020) \\
\hline 3 & Poaceae & $\begin{array}{l}\text { Sorghum } \\
\text { bicolor } \mathrm{L} .\end{array}$ & Sorghum & $\begin{array}{l}\text { Sharanabasappa et al. (2018b), Jaba } \\
\text { et al. (2019), Venkateswarlu et al. } \\
\text { (2018), and ICAR - Indian Institute of } \\
\text { Millets Research (2019) }\end{array}$ \\
\hline 4 & Poaceae & $\begin{array}{l}\text { Eleusine } \\
\text { coracana } \\
\text { (L.) Gaertn }\end{array}$ & $\begin{array}{l}\text { Finger } \\
\text { millet }\end{array}$ & $\begin{array}{l}\text { ICAR - Indian Institute of Millets } \\
\text { Research (2019), Jaba et al. (2019), } \\
\text { and Venkateswarlu et al. (2018) }\end{array}$ \\
\hline 5 & Poaceae & $\begin{array}{l}\text { Pennisetum } \\
\text { glaucum } \\
\text { L. R. Br. }\end{array}$ & $\begin{array}{l}\text { Pearl } \\
\text { millet }\end{array}$ & $\begin{array}{l}\text { ICAR - Indian Institute of Millets } \\
\text { Research (2019), Jaba et al. (2019), } \\
\text { and Venkateswarlu et al.(2018) }\end{array}$ \\
\hline 6 & Poaceae & $\begin{array}{l}\text { Echinochloa } \\
\text { frumentacea } \\
\text { Link }\end{array}$ & $\begin{array}{l}\text { Barnyard } \\
\text { millet }\end{array}$ & Roopika et al. (2020) \\
\hline 7 & Poaceae & $\begin{array}{l}\text { Saccharum } \\
\text { officinarum } \\
\text { L. }\end{array}$ & Sugarcane & $\begin{array}{l}\text { Srikanth et al. (2018), Chormule et al. } \\
\text { (2019), and Matti and Patil (2019) }\end{array}$ \\
\hline 8 & Poaceae & $\begin{array}{l}\text { Brachiaria } \\
\text { mutica } \\
\text { (Forssk.) }\end{array}$ & Para grass & Maruthadurai and Ramesh (2020) \\
\hline 9 & Poaceae & $\begin{array}{l}\text { Megathyrsus } \\
\text { maximus } \\
\text { (Jacq.) }\end{array}$ & $\begin{array}{l}\text { Guinea } \\
\text { grass }\end{array}$ & Maruthadurai and Ramesh (2020) \\
\hline 10 & Amaranthaceae & $\begin{array}{l}\text { Amaranthus } \\
\text { viridis L. }\end{array}$ & $\begin{array}{l}\text { Green } \\
\text { amaranth }\end{array}$ & Maruthadurai and Ramesh (2020) \\
\hline 11 & Amaranthaceae & $\begin{array}{l}\text { Beta vulgaris } \\
\text { subsp. } \\
\text { vulgaris } \mathrm{L} \text {. }\end{array}$ & $\begin{array}{l}\text { Sugar } \\
\text { beet }\end{array}$ & Shanthi et al. (2020) \\
\hline
\end{tabular}

collection of pheromone trap data are available (FAO 2020b; McGrath et al. 2018). In Africa, bucket traps and locally constructed traps are showing promise, while delta traps were found to capture fewer FAW moths. Determination of the most effective pheromone lure for FAW is less straight forward. While many pheromone lures attract about the same number of moths, the number of nontarget moths can vary significantly. In India, funnel-type pheromone traps are used for monitoring the FAW. Since the pest has invaded recently in India, studies on pheromone trap catches are going on. The maximum number of trap catches of FAW was recorded during 46th and 45th standard weeks in maize and sorghum crops (Jaba et al. 2019). There is an urgent need to develop FAW-species-specific pheromone lure with accurate pheromone blend ratio for effective pheromone lure catches. 


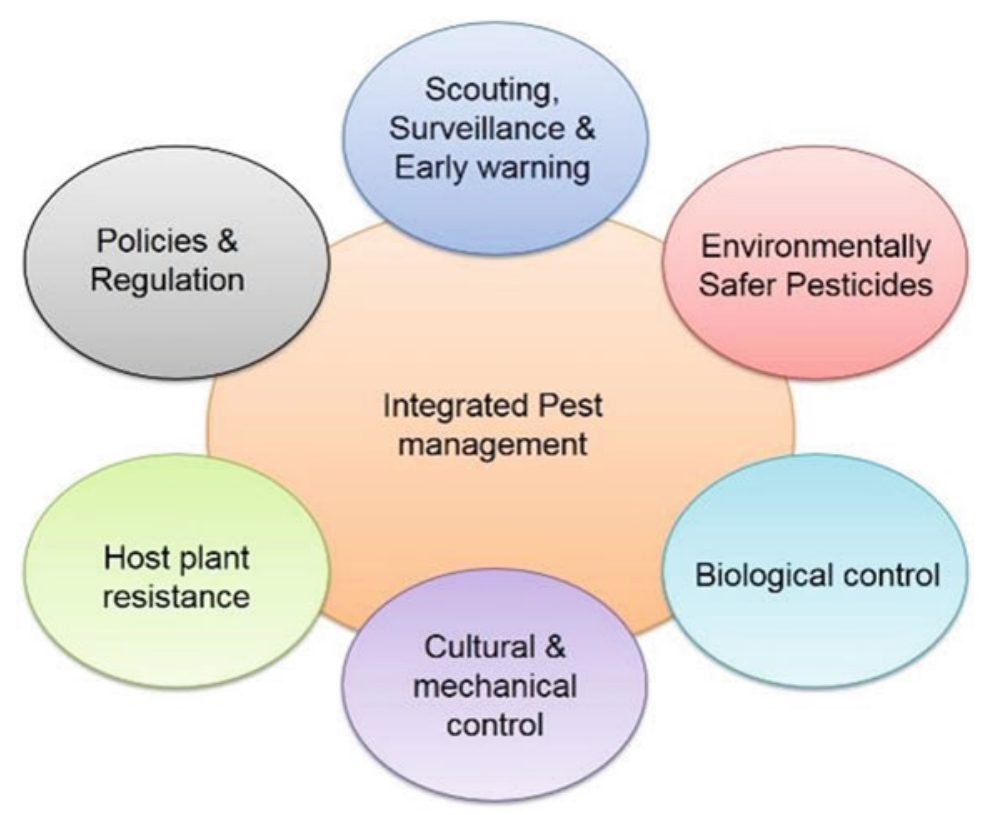

Fig. 8.4 Key components of an IPM-based strategy for FAW management

Given the visible nature of FAW, formal surveillance (including the use of appropriate pheromone traps) should be complemented by use of communitybased crowd-sourcing techniques. Similarly, understanding and predicting dispersal patterns are essential if any early warning system is to be developed for effective control. Progress has been made on FAW environmental suitability models which can help to prioritize and improve scouting and trapping activities (Early et al. 2018). FAO established a Fall Armyworm Monitoring and Early Warning System (FAMEWS), which consists of the FAMEWS mobile app that was launched in March 2018 and a global platform that was established in July 2018.

\subsubsection{Mechanical, Cultural, and Agroecological Management}

The female moth lays up to 1500 eggs. These eggs are seen with naked eyes, and thus, farmers can identify and kill these egg masses with adequate training, as to prevent the caterpillars from damaging the crops. Manipulation of planting dates to ensure that the most susceptible stages of crop growth do not coincide with periods of peak moth activity is a well-known strategy to control lepidopteran pests. Planting early and adhering to regional planting calendar (avoiding late planting) will allow the maize crops to mature before buildup of high pest population. Tillage may destroy the pupae of lepidopteran pests (particularly in the case of FAW), as the pupae reside in the soil. Proper fertilization may also reduce plant damage by 
increasing plant defenses or increase it by making the plant more attractive to ovipositioning females. Intercrops may reduce crop infestation by lepidopteran pests through four possible ways: (i) by decreasing the movement of the caterpillars between maize plants, (ii) by decreasing the oviposition on maize plants, (iii) by emitting volatiles repelling ovipositioning females, and (iv) by hosting natural enemies.

The abundance of wide-ranging natural enemies of FAW (e.g., predatory arthropods, insectivorous birds, and/or bats) is a function of the availability of suitable habitat in the landscape, including hedgerows and non-crop habitat. Zero tillage and mulching may also create a favorable habitat for natural enemies and provide them with alternative prey. Push-pull strategy is another potential option for agroecological management of FAW (Midega et al. 2018).

\subsubsection{Host Plant Resistance}

Integrated pest management involving host plant resistance is a very important component against fall armyworm (Prasanna et al. 2018b).

Maize germplasm with naturally occurring or "native" genetic resistance to FAW was developed by CIMMYT in Mexico, where the pest was prevalent for several decades. Several research organizations such as CIMMYT (Mexico), EMBRAPA (Brazil), USDA-ARS (Mississippi), and universities in the United States led to the development of number of improved maize inbred lines with partial resistance to fall armyworm (Prasanna et al. 2018b). Similarly, sorghum and pearl millet germplasm also have native genetic resistance to sorghum stem borer; it may also be suitable for FAW developed by ICRISAT in India and Africa. Molecular biology tools now provide great potential for accelerating the development of new and promising varieties that could provide tolerance/resistance to fall armyworm and a host of other biotic stresses. Breeding for native genetic resistance to FAW is a medium- to long-term strategy and requires effective coordination and resources from the national partners and international organizations, like CIMMYT.

Transgenic/Bt maize producing endotoxins from the soil bacterium Bacillus thuringiensis $(B t)$ is one of the potential options for controlling a lepidopteran insect pest, like FAW. Bt maize technology is one of the most effective options to manage the FAW in both the United States and Brazil. In Africa, the TELA project has been testing $B t$ maize under confined field trials (CFTs) in six African countries to demonstrate the safety, efficacy, and yield benefits of the $B t$ maize under African conditions. Some of the African regulatory agencies have built capacity for sciencebased decision-making to address issues and societal concerns regarding $B t$ technology safety, effectiveness, and performance. Pyramiding transgenes with different novel modes of action (e.g., Cry + Vip genes) could be more effective and durable compared to single-gene deployment. Fast-tracked release of elite $B t$ maize varieties with FAW resistance could provide another powerful option in the IPM toolbox for FAW management. This, however, needs to go hand in hand with proper stewardship and insect resistance management to ensure durability of the technology. 


\subsubsection{Biological Control}

Identification and use of natural enemies form basic component in IPM. Wherever necessary, inundative/augmentative release of well-validated biological enemies against FAW (e.g., Trichogramma sp. and Telenomus sp.; the egg parasitoids) should be taken up as a priority by public and private sector institutions in India. Several natural enemies have already been identified in African countries and in India, with reasonable levels of efficacy. In addition to biological control agents, bio-rational pesticides (like neem-based preparations) could also be potentially incorporated into the IPM-based strategies.

Survey carried out in the East African countries (Ethiopia, Kenya, and Tanzania) revealed four hymenopteran (Cotesia icipe Fernandez-Triana and Fiaboe (Braconidae), Chelonus curvimaculatus Cameron (Braconidae), Coccygidium luteum Brullé (Braconidae), Charops ater Szépligeti (Icheneumonidae)) and one dipteran (Palexorista zonata (Curran) (Tachinidae)) parasitoids (Sisay et al. 2018). With the exception of $C$. curvimaculatus, an egg-larval parasitoid, the rest are larval parasitoids. All these four species are native to Africa and not reported before from Africa or North and South America. Among these, one of the dominant larval parasitoids, $C$. icipe, with the high parasitism can be used for the management of fall armyworm (Sisay et al. 2018).

The two year surveys of fall armyworm natural enemies in maize and sorghum fields in Nigeria reported the egg parasitoids Trichogrammatoidea sp., Trichogramma sp., and Telenomus sp. and one egg-larval parasitoid Chelonus sp. and the other four larval parasitoids, viz., Cotesia sp., Charops sp., and unidentified ichneumonid and tachinid fly (Amadou et al. 2018).

The fungal pathogens like Metarhizium anisopliae and Beauveria bassiana are found effective against the eggs and second instar larvae of fall armyworm. Under laboratory conditions, $M$. anisopliae caused egg mortalities of 79.5\%-87.0\%, and B. bassiana recorded mortality of $30 \%$ to second instar larvae. The total mortality of eggs and early-stage larval mortality with $M$. anisopliae was as high as $96 \%$ with some fungal isolates (Akutse et al. 2019). Shylesha et al. (2018) recorded the egg parasitoids, viz., Telenomus sp., Trichogramma sp., Glyptapanteles creatonoti (Viereck), Campoletis chlorideae Uchida (Ichneumonidae), and Cotesia ruficrus on $S$. frugiperda larvae collected from the maize fields in Karnataka, India. Navik et al. (2019) recorded the natural parasitism (25.64\%) by the Trichogramma sp. on fall armyworm eggs from Karnataka. Gupta et al. (2019) reported Cotesia ruficrus as an indeterminate larval-pupal ichneumonid parasitoid on fall armyworm, and the emergence of $C$. ruficrus adults from FAW larva is 11-29 wasps/larva. Sharanabasappa et al. (2019a) recorded larval parasitoids, namely, Coccygidium melleum (Roman), Odontepyris sp., and Eriborus sp. from Karnataka. In kharif 2019, the activity of two egg parasitoids, namely, Trichogramma sp. and Telenomus remus, was recorded from Shivamogga and Davanagere districts of Karnataka (Sharanabasappa et al. 2020a). Two predatory pentatomids, Eocanthecona furcellata and Andrallus spinidens, feeding on the larva of fall armyworm are reported by Shylesha and Sravika (2018). During the monsoon season (kharif) 2018, natural 
infestation of entomopathogenic fungi, Metarhizium (=Nomuraea) rileyi was noticed on $S$. frugiperda with its infection ranging from $1.87 \%$ to $18.30 \%$ (Mallapur et al. 2018) and 10\% to $15 \%$ (Sharanabasappa et al. 2019a). A comprehensive list of natural enemies reported from India is in Table 8.3.

\subsubsection{Pesticide and Pesticide Risk Management}

\subsubsection{Pesticide}

Insecticides are the necessary components in the insect pest management. The judicious use of insecticides is necessary for proper and effective pest management of the pest and least disturbance to the natural enemies and to the environment. The field efficacies of different insecticides against fall armyworm were investigated by many workers.

Another major issue with fall armyworm is the development of quick resistance to insecticides because of its behavioral and physiological factors ( $\mathrm{Yu}$ 1991). Gutiérrez-Moreno et al. (2019) studied the field-evolved resistance of the fall armyworm to different insecticides. The $\mathrm{LD}_{50}$ values for flubendiamide, chlorantraniliprole, emamectin benzoate, and spinetoram against fall armyworm populations are collected from Mexico and Puerto Rico. The LD50 values of Puerto Rico are higher as compared to Mexico values because these insecticides are being used against FAW from many years in Puerto Rico.

Belay et al. (2012) studied the efficacy of different insecticides against FAW larvae under laboratory conditions. The insecticides like spinetoram, acephate, and thiodicarb recorded maximum $(\geq 60 \%)$ larval mortality as compared to lambda cyhalothrin and chlorantraniliprole. Similarly, Sisay et al. (2019) observed the insecticidal mortality to larvae of FAW under laboratory conditions showed that lambda cyhalothrin 5 EC recorded $77.8 \%$ larval mortality, and the next best were chlorantraniliprole plus lambda cyhalothrin $150 \mathrm{SC}$ (62.2\% mortality); spinetoram $120 \mathrm{SC}$ recorded highest $(61.1 \%)$ larval mortality and chlorantraniliprole $200 \mathrm{SC}$ (60\% mortality). At 48 and $72 \mathrm{~h}$ after treatment, spinetoram $120 \mathrm{SC}$ caused the highest larval mortality of $96.7 \%$ and $100 \%$ larval mortality, respectively, whereas lambda cyhalothrin 5 EC recorded $96.7 \%$ mortality $48 \mathrm{~h}$ and $72 \mathrm{~h}$ after treatment applications. At present, the Central Insecticide Board and Registration Committee, India, recommended the ad hoc use of chlorantraniliprole 18.5 SC, thiamethoxam $12.6 \%$ + lambda cyhalothrin $9.5 \%$ ZC, emamectin benzoate $5 \mathrm{SG}$, and spinetoram 11.7 SC for fall armyworm management (DPPQS 2019). Mallapur et al. (2019) evaluated the efficacy of some insecticides both in laboratory and field experiments. The laboratory results revealed that spinetoram 11.7 SC and emamectin benzoate 5 SG were significantly superior over other treatments with $100 \%$ mortality at 60 hours after treatment. Under field conditions, spinetoram 11.7 SC, emamectin benzoate $5 \mathrm{SG}$, and spinosad $45 \mathrm{SC}$ reduced the larval population to $98.13,96.26$, and $96.26 \%$, respectively, at 7 days after treatment. Muralimohan and Dileepkumar (2019) studied the efficacy of different insecticides as both sprays and poison baits (applied in whorls of infested plants). Spinetoram 11.7 SC, chlorantraniliprole 18.5 


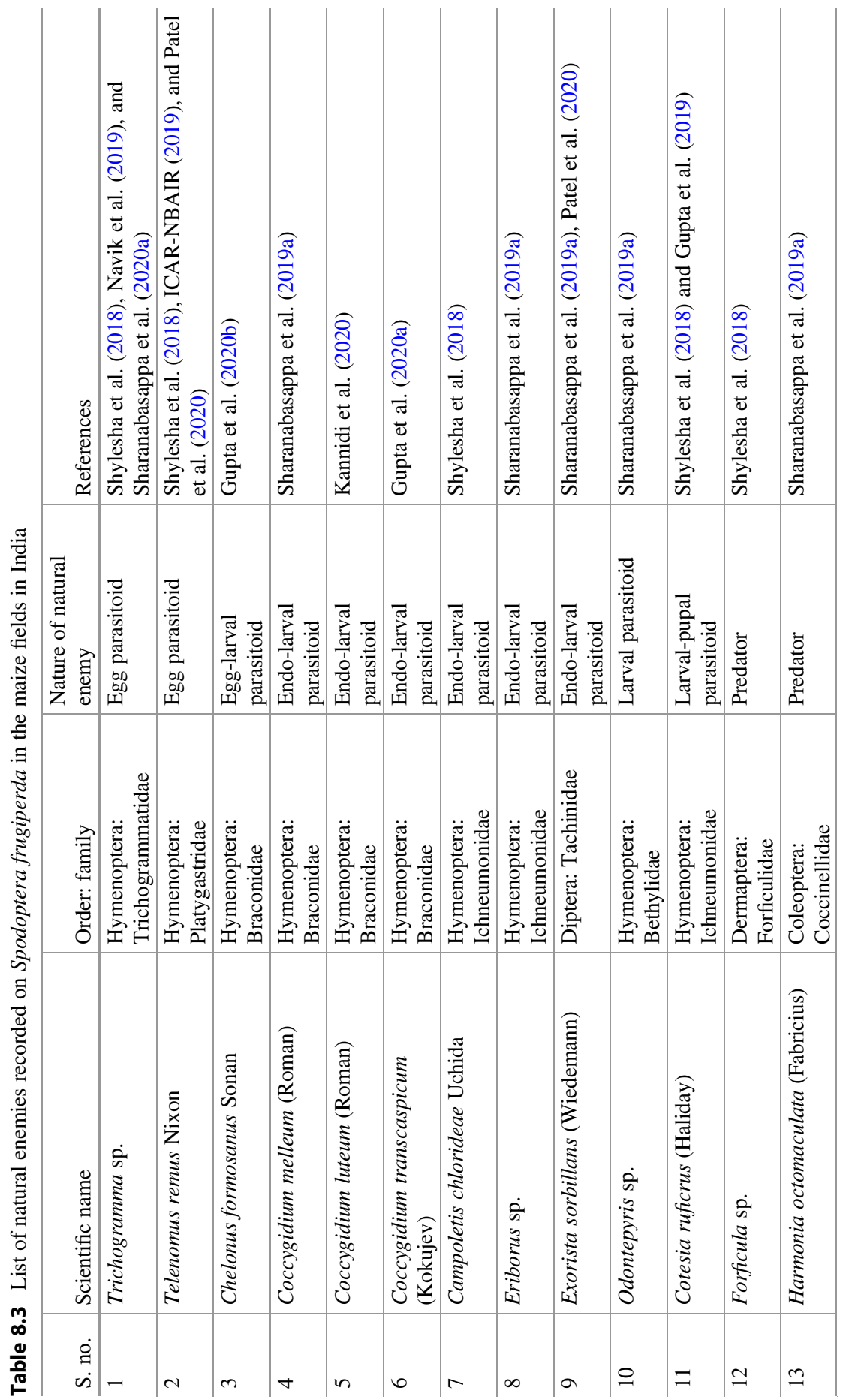




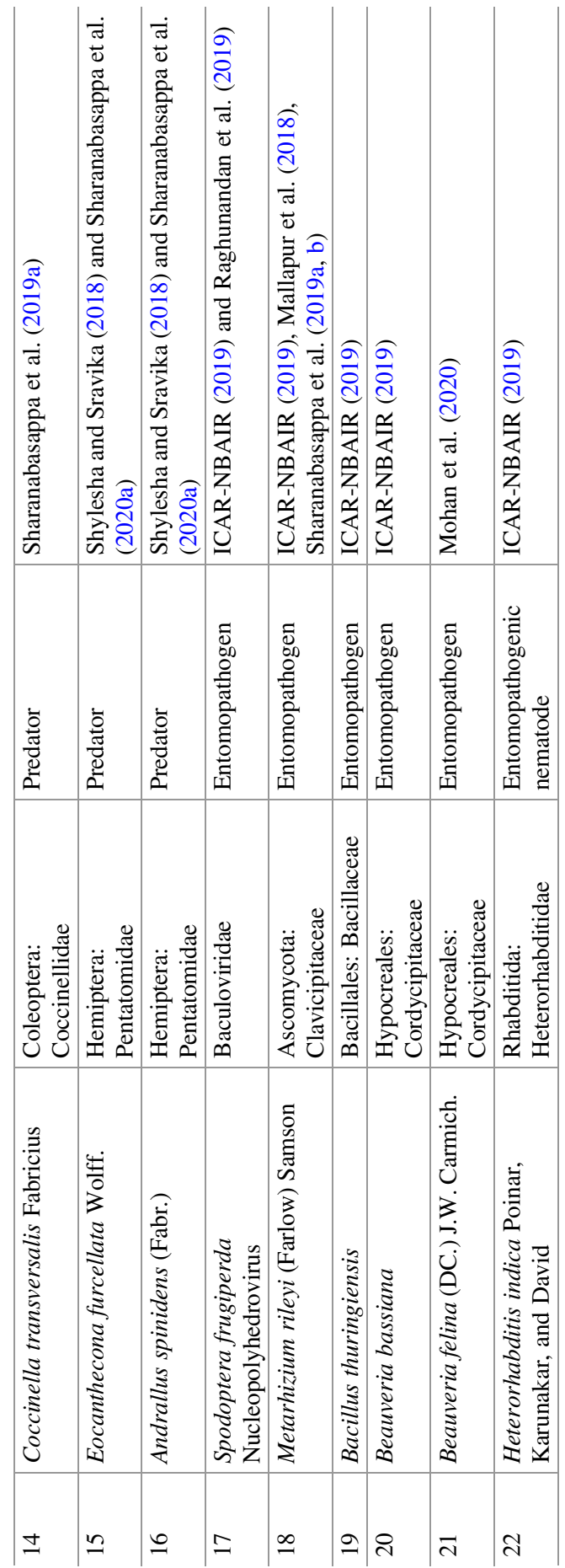


SC, and novaluron $10 \mathrm{EC}$ recorded highest larval mortality (93.53\% to $96.76 \%$ reduction over untreated control) under laboratory conditions. Field studies suggested that bait application was as effective as foliar sprays involving same insecticide. The results indicated that greener molecules with a waiting period of $<3-5$ days were very effective as baits, and cost of plant protection was substantially low when used as baits (up to $42 \%$ cost reduction). This finding provides an opportunity for the growers not only to reduce the cost of protection but also to make the food safe for consumption, particularly as fodder maize fed to the animals. Among the insecticides and biopesticides tested, thiodicarb 75\% WP at $1 \mathrm{~g}$ per lit, emamectin benzoate $5 \mathrm{SG}$ at $0.5 \mathrm{~g}$ per lit, and spinetoram $11.7 \mathrm{SC}$ at $0.5 \mathrm{ml}$ per lit were found to be very effective against FAW, while pongamia oil at $6 \mathrm{ml}$ per lit of water was also found to be most effective among the biopesticides (Jaba et al. 2019). Similarly, Sharanabasappa et al. (2020b) found that chlorantraniliprole $18.5 \mathrm{SC}$ at $37 \mathrm{~g}$ ai per ha, emamectin benzoate $5 \mathrm{SG}$ at $12.5 \mathrm{~g}$ ai per ha, and spinetoram11.7 SC at $29.2 \mathrm{~g}$ ai per ha are suitable insecticides in managing the fall armyworm.

\subsubsection{Pesticide Risk Management}

Pesticides are classified based on hazards and risks which are used for the control of fall armyworm (Jepson et al. 2018). The suggested requirements for pesticide recommend the use of products that can be used with minimal protective clothing (PPE), which allows the reentry to the field, a day or less after spray or treatment. While there are plenty of crop protection products available across Africa and Asia, not all of them may be effective in controlling FAW. Products that farmers have been using range from chemicals, such as emamectin benzoate, chlorpyrifos, chlorantraniliprole, cyantraniliprole, emamectin benzoate, and lambda cyhalothrin, to biological, such as $B t$, spinosad, spinetoram, and plant and biological extracts. Application of insecticides should be done late in the evening when the larvae are active (not hiding within the whorls); the larvae mostly feed in the early morning or at night when temperatures are not high and when there is no bright light.

Biological pesticides and natural enemies have been extensively studied, and a guide to candidate FAW biopesticides and biological control agents is published recently (Bateman et al. 2018). These include pesticides registered in 30 countries, 11 in Americas and 19 in African countries. Among the fifty biopesticide reported, twelve are found to be effective against FAW outside Africa, and these biopesticides are already registered to manage other pests in some African countries. A similar inventory needs to be drawn up soon in Asian countries.

\subsection{Conclusions}

Within a short span of 3-4 years, fall armyworm has spread to several countries across Africa and the Asia-Pacific, causing huge damage to the crops, especially maize, sorghum, and pearl millet in particular affecting the food surety, income, and subsistence of million farmers. Intensive research is required for developing economic thresholds, besides various aspects of the biology and behavior of fall 
armyworm in continents like Africa and Asia. Besides monitoring and surveillance, environmentally sustainable fall armyworm management requires effective integration of various approaches, including biological control, environmentally safe pesticides including biopesticides, host plant resistance, and agroecological management. In summary, fall armyworm poses a complex challenge and needs to be managed through well-coordinated, inter-institutional, and multidisciplinary efforts.

\section{References}

Abrahams P, Bateman M, Beale T, Clottey V, Cock M, Colmenarez Y, Corniani N, Day R, Early R, Godwin J et al (2017) Fall armyworm: impacts and implications for Africa. Evid Note 2:1-144

Akutse KS, Kimemia JW, Ekesi S, Khamis FM, Ombura OL, Subramanian S (2019) Ovicidal effects of entomopathogenic fungal isolates on the invasive fall armyworm Spodoptera frugiperda (Lepidoptera: Noctuidae). J Appl Entomol 143(6):1-9. https://doi.org/10.1111/jen. 12634

Amadou L, Baoua I, Ba MN, Karimoune L, Muniappan R (2018) Native parasitoids recruited by the invaded fall army worm in Niger. Indian J Entomol 80:1253-1254

Anonymous (2019) Press information, bureau government of India, Ministry of Agriculture and farmers welfare, Government is taking several steps to control the spread of fall Army worm, ShriTomar. https://pib.gov.in/newsite/PrintRelease.aspx?relid=190750

Bajracharya ASR, Bhat B, Sharma P, Shashank PR, Meshram NM, Hashmi TR (2019) First record of fall army worm Spodoptera frugiperda (J. E. Smith) from Nepal. Indian J Entomol 81 (4):635-639

Bateman ML, Day RK, Luke B, Edgington S, Kuhlmann U, Cock MJW (2018) Assessment of potential biopesticide options for managing fall armyworm (Spodoptera frugiperda) in Africa. J Appl Entomol 142(9):805-811

Belay DK, Huckaba RM, Foster JE (2012) Susceptibility of the fall armyworm, Spodoptera frugiperda (Lepidoptera: Noctuidae) at Santa Isabel, Puerto Rico, to different insecticides. Fla Entomol 95:476-478

Bueno R, Carneiro TR, Bueno AF, Pratissoli D, Fernandes OA, Vieira SS (2010) Parasitism capacity of Telenomus remus Nixon (Hymenoptera: Scelionidae) on Spodoptera frugiperda (smith) (Lepidoptera: Noctuidae) eggs. Braz Arch Biol Technol 53:133-139

CABI (2019) Invasive Species Compendium :Spodoptera frugiperda (Fall armyworm). Available online at https://www.cabi.org/ISC/datasheet/29810. Accessed on 02/06/2019

Chaudhary DP, Kumar A, Mandhania SS, Srivastava P, Kumar RS (2012) Maize as fodder-an alternative approach. Directorate of Maize Research, New Delhi $32 \mathrm{p}$

Chormule A, Shejawal N, Sharanabasappa, Kalleshwaraswamy CM, Asokan R, MahadevaSwamy HM (2019) First report of the fall armyworm, Spodoptera frugiperda (J. E. Smith) (Lepidoptera, Noctuidae) on sugarcane and other crops from Maharashtra, India. J Entomol Zool Stud 7 (1):114-117

Day R, Abrahams P, Bateman M, Beale T, Clottey V, Cock M, Early R, Godwin J, Gomez J, Witt A (2017) Fall armyworm: impacts and implications for Africa. Outlooks Pest Manag 28:196-201

Dively G (2018) Management of fall armyworm (Spodoptera frugiperda) with emphasis on Bt Transgenic Technology. https://usunrome.usmission.gov/wp-content/uploads/sites/54/2018Africa-FAW-Talk_Rome-pdf.pdf

DMR (2012) Maize production Technologies in India. Directorate of Maize Research, New Delhi, p 100

DPPQS (2019) Package of practices (POPs) for the management of fall Army worm (FAW) in grain corn, sweet corn, baby corn and fodder maize http://ppqs.gov.in/sites/default/files/pop_faw_ corn_for_cipmcs.pdf 
Du Plessis H, Schlemmer ML, Van den Berg J (2020) The effect of temperature on the development of Spodoptera frugiperda (Lepidoptera: Noctuidae). Insects 11(4):228. https://doi.org/10.3390/ insects11040228

Early R, González-Moreno P, Murphy ST, Day R (2018) Forecasting the global extent of invasion of the cereal pest Spodoptera frugiperda, the fall armyworm. Neo Biota 40:25-50

Evans T, Kumschick S, Blackburn TM (2016) Application of the environmental impact classification for alien taxa (EICAT) to a global assessment of alien bird impacts. Divers Distrib 22 (9):919-931

FAO (2018) World Food and Agriculture - Statistical Pocket Book 2018. Rome. 254 pp. Licence: CC BY-NC-SA 3.0 IGO

FAO (2019) Regional workshop for Asia sustainable management of fall armyworm. Department of Agriculture Kunming City, Yunnan Province, China, 11-15 November 2019

FAO (2020a) Global Monitoring for Fall Armyworm Control. Available online: http://www.fao. org/fall-armyworm/monitoring-tools/faw-map/en/. Accessed on 20 June 2020

FAO (2020b) Forecasting threats to the food chain affecting food security in countries and regions. Food Chain Crisis Early Warning Bulletin No. 34, January-March 2020. Rome

Ganiger PC, Yeshwanth HM, Muralimohan K, Vinay N, Kumar ARV, Chandrashekara K (2018) Occurrence of the new invasive pest, fall armyworm, Spodoptera frugiperda (J.E. Smith) (Lepidoptera: Noctuidae) in the maize fields of Karnataka, India. Curr Sci 115:621-623

Goergen G, Kumar PL, Sankung SB, Togola A, Tamo M (2016) First report of outbreaks of the fall armyworm Spodoptera frugiperda (J. E. Smith) (Lepidoptera, Noctuidae), a new alien invasive pest in west and Central Africa. PLoS One 11(10):e0165632. https://doi.org/10.1371/journal. pone. 0165632

Gouin A, Bretaudeau A, Nam K, Gimenez S, Aury JM, Duvic B et al (2017) Two genomes of highly polyphagous lepidopteran pests (Spodoptera frugiperda, Noctuidae) with different hostplant ranges. Sci Rep 7:11816. https://doi.org/10.1038/s41598-017-10461-4

Gupta A, Ramesh Babu S, Sampath Kumar M (2019) Cotesia ruficrus (Haliday, 1834) (Hymenoptera: Braconidae) emerging as a common natural parasitoid of Spodoptera frugiperda (J. E. Smith) (Lepidoptera: Noctuidae) in Indian maize fields. J Biol Control 33(3):193-196

Gupta A, Lakshmi Soujanya P, Van Achterberg C, Sekhar JC (2020a) Coccygidium transcaspicum (Kokujev) (Hymenoptera: Braconidae) parasitizing larvae of invasive pest Spodoptera frugiperda (J. E. Smith) (Lepidoptera: Noctuidae) in India. Zootaxa 4750(2):293-297

Gupta A, Lalitha Y, RichaVarshney ANS, Van Achterberg C (2020b) Chelonus formosanus Sonan (Hymenoptera :Braconidae) an egg-larval parasitoid of the invasive pest Spodoptera frugiperda (J. E. Smith) (Lepidoptera: Noctuidae) amenable to laboratory mass production in India. J Entomol Zool Stud 8(1):1521-1524

Gutiérrez-Moreno R, Mota-Sanchez D, Blanco CA, Whalon M, Terán-Santofimio H, RodriguezMaciel JC, DiFonzo C (2019) Field-evolved resistance of the fall armyworm (Lepidoptera: Noctuidae) to synthetic insecticides in Puerto Rico and Mexico. J Econ Entomol 112 (2):792-802

ICAR - Indian Institute of Millets Research (2019) Annual Report 2018-19.Rajendranagar, Hyderabad 500 030, India $152 \mathrm{p}$

ICAR- IIMR (2019) Annual Report 2018-19, ICAR-Indian Institute of Maize Research, Punjab Agricultural University Campus, Ludhiana - 141004, pp 103

ICAR-NBAIR (2019) Annual Report 2018-19, ICAR - National Bureau of Agricultural Resources, Bengaluru, India, vi + 122pp

Jaba J, Suraj Mishra, Pankaj Maknwar (2019) Strategies for sustainable management of fall armyworm, Spodoptera frugiperda (J.E. Smith) in sorghum. Paper presented in XIX International Plant Protection Congress IPPC2019, 10-14 November, 2019, Hyderabad, Telangana, India

Jepson PC, Murray K, Bach O, Kachigamba D, Ndeithi F, KibakiMiano J, McCracken T, Onyango D, Nthegna I, Agboka K, Byantwala S, De Groote H (2018) Pesticide hazard and risk management, and compatibility with IPM, pp 29-44. In: Prasanna, BM, Huesing JE, 
Eddy R, Peschke VM (eds) Fall Armyworm in Africa: a guide for integrated pest management, First Edition. Available at: https://www.usaid.gov/sites/default/files/documents/1867/FallArmyworm-IPM-Guide-for-AfricaJan_30-2018.pdf

Jiang YY, Liu J, Xie MC, Li YH, Yang JJ, Zhang ML, Qiu K (2019) Observation on law of diffusion damage of Spodoptera frugiperda in China in 2019. Plant Prot 45:10-19

Kannidi S, Chinniah C and Shanthi M (2020) Natural occurrence of a larval parasitoid, Coccygidium luteum Brulle (Braconidae: Hymenoptera) on fall armyworm, Spodoptera frugiperda (J. E. Smith) in Madurai District, Tamil Nadu. Paper presented in International seminar on Transboundry Pest Management March 4-5 2020, TNAU, Coimbatore, Tamil Nadu, India. PP 171

Luginbill P (1928) The fall armyworm (V 34). US Dept. of Agriculture

Mahadevaswamy HM, Asokan R, Kalleshwaraswamy CM, Sharanabasappa D, Prasad YG, Maruthi MS, Shashank PR, Ibemu Devi N, Surakasula A, Adarsha S, Srinivas A, Rao S, Vidyasekhar SRM, Shyam Sunder Reddy G, Nagesh SN (2018) Prevalence of "R" strain and molecular diversity of fall armyworm, Spodoptera frugiperda (J.E. Smith) (Lepidoptera: Noctuidae) in India. Indian J Entomol 80(3):544-553

Mallapur CP, Naik AK, Hagari S, Praveen T, Patil RK, Lingappa S (2018) Potentiality of Nomuraea rileyi (Farlow) Samson against the fall armyworm, Spodoptera frugiperda (J E Smith) infesting maize. J Entomol Zool Stud 6(6):1062-1067

Mallapur CP, Naik AK, Hagari S, Praveen T, Naik M (2019) Laboratory and field evaluation of new insecticide molecules against fall armyworm, Spodoptera frugiperda (J. E. Smith) on maize. J Entomol Zool Stud 7(4):869-875

Maruthadurai R, Ramesh R (2020) Occurrence, damage pattern and biology of fall armyworm, Spodoptera frugiperda (J.E. smith) (Lepidoptera: Noctuidae) on fodder crops and green amaranth in Goa. India. Phytoparasitica 48:15-23

Matti PV, Patil SB (2019) Occurrence of invasive species of armyworm, Spodopterafrugiperda on sugarcane in Belgaum, Karnataka, India. Internat J Plant Prot 12(1):36-39

McGrath D, Huesing JE, Beiriger R, Nuessly G, Tepa-Yotto TG, Hodson D, Kimathi E, Felege E, AbahObaje J, Mulaa M, Mendes AP (2018) Monitoring, surveillance, and scouting for fall armyworm. Fall Armyworm in Africa: a Guide for Integrated Pest Management. pp. 11-28

Midega CAO, Pittchar JO, Pickett JA, Hailu GW, Khan ZR (2018) A climate-adapted push-pull system effectively controls fall armyworm, Spodoptera frugiperda (J. E. Smith), in maize in East Africa. Crop Protect 105:10-15

Mitchell ER, McNeil JN, Westbrook JK, Silvain JF, Lalanne-Cassou B, Chalfant RB, Pair SD, Waddill VH, Sotomayor-Rios A, Proshold FL (1991) Seasonal periodicity of fall armyworm, (Lepidoptera: Noctuidae) in the Caribbean basin and Northward to Canada. J Entomol Sci 26 (1):39-50

Mohan M, Poornesha B, Ramanujam B, Shivakumar G (2020) Natural occurrence of entomopathogenic fungi Beauveria felina (DC.) J. W. Carmich on fall armyworm, Spodoptera frugiperda (J. E. Smith). Paper presented in International Seminar on Transboundry Pest Management March 4-5 2020, TNAU, Coimbatore, Tamil Nadu, India, p 168

Montezano DG, Specht A, Sosa-Gómez DR, Roque-Specht VF, Sousa-Silva JC, Paula-Moraes SV, Peterson JA, Hunt T (2018) Host plants of Spodoptera frugiperda (Lepidoptera: Noctuidae) in the Americas. Afr Entomol 26:286-300

Muralimohan K, Dileepkumar NT (2019) Management of new invasive pest, Spodoptera frugiperda(J.E. Smith) using green chemistry insecticides based poison baits. Paper presented in XIX international plant protection congress IPPC2019 10-14 November 2019, Hyderabad, Telangana, India

Murúa G, Molina-Ochoa J, Coviella C (2006) Population dynamics of the fall armyworm, Spodoptera frugiperda (Lepidoptera: Noctuidae) and its parasitoids in northwestern Argentina. Fla Entomol 89:175-182

Nagoshi RN, Meagher RL (2004) Seasonal distribution of fall armyworm (Lepidoptera: Noctuidae) host strains in agricultural and turf grass habitats. Environ Entomol 33:881-889 
Nagoshi RN, Meagher RL (2008) Review of fall armyworm (Lepidoptera: Noctuidae) genetic complexity and migration. Fla Entomol 91(4):546-554

Nagoshi RN, Koffi D, Agboka K, Tounou KA, Banerjee R, Jurat-Fuentes JL, Meagher LR (2017) Comparative molecular analyses of invasive fall armyworm in Togo reveal strong similarities to populations from the eastern United States and the Greater Antilles. PLoS One 12(7):e0181982

Nagoshi RN, Dhanani I, Asokan R, Mahadevaswamy HM, Kalleshwaraswamy CM, Sharanabasappa et al (2019) Genetic characterization of fall armyworm infesting South Africa and India indicate recent introduction from a common source population. PLoS One 14(5): e0217755. https://doi.org/10.1371/journal.pone.0217755

Nagoshi RN, Htain NN, Boughton D et al (2020) Southeastern Asia fall armyworms are closely related to populations in Africa and India, consistent with common origin and recent migration. Sci Rep 10:1421. https://doi.org/10.1038/s41598-020-58249-3

Navasero MV, Navasero MM, Burgonio GAS, Ardez KP, Ebuenga MD, Beltran MJB, Bato MB, Gonzales PG, Magsino GL, Caoili BL, Barrion-Dupo ALA, Aquino MFGM (2019) Detection of the fall armyworm, Spodoptera frugiperda (J. E. Smith) (Lepidoptera: Noctuidae) using larval morphological characters, and observations on its current local distribution in the Philippines. Philipp Ent 33(2):171-184

Navik O, Jalali SK, Lalitha Y (2019) Natural parasitism by trichogrammatids (Hymenoptera: Trichogrammatidae) on lepidopteran eggs under diverse cropping system. J Biol Control 33 (3):279-284

Oliver AD, Chapin JB (1981) Biology and illustrated key for the identification of twenty species of economically important noctuid pests. Louisiana Agricultural Experiment Station Bulletin, No. 733

Padhee AK, Prasanna BM (2019) The emerging threat of fall armyworm in India. Indian Farm 69 (1):51-54

Pashley DP (1986) Host associated genetic differentiation in fall armyworm (Lepidoptera: Noctuidae): a sibling species complex? Ann Entomol Soc Am 79:898-904

Pashley DP, Johnson SJ, Sparks AN (1985) Genetic population structure of migratory moths: the fall armyworm (Lepidoptera: Noctuidae). Ann Entomol Soc Am 78:756-762

Pashley DP, Sparks TC, Quisenberry SS, Jamjanya T, Dowd PF (1987) Two fall armyworm strains feed on corn, rice and Bermuda grass. La Agric Mag 30:8-9

Patel KM, Shinde, CU, Siddhapara (2020) Occurrence of fall armyworm, Spodoptera frugiperda (J. E. Smith) and its natural enemies in South Gujarat (Western India). Paper presented in International seminar on Transboundry Pest Management March 4-5 2020, TNAU, Coimbatore, Tamil Nadu, India. PP 155

Pimentel D, Zuniga R, Morrison D (2005) Update on the environmental and economic costs associated with alien invasive species in the United States. Ecol Entomol 52:273-288

Prasanna BM, Huesing JE, Eddy R, Peschke VM (2018a) Fall armyworm in Africa: a guide for integrated Pest management, 1st edn. CIMMYT, Mexico, CDMX

Prasanna BM, Bruce A, Winter S, Otim M, Asea G et al (2018b) Host plant resistance to fall armyworm. In: Prasanna BM et al (eds) Fall armyworm in Africa: a guide for integrated Pest management, 1st edn. CIMMYT, Mexico, CDMX, pp 45-62

Prowell DP, McMichael M, Silvain JF (2004) Multilocus genetic analysis of host use, introgression and speciation in host strains of fall armyworm (Lepidoptera: Noctuidae). Ann Entomol Soc Am 97:1034-1044

QGDAF (2020) First mainland detection of fall armyworm, Australia: Queensland Government Department of Agriculture and Fisheries. https://www.daf.qld.gov.au/news-media/media-cen tre/biosecurity/news/first-mainland-detection-of-fall-armyworm

Raghunandan BL, Patel NM, Dave HJ, Mehta DM (2019) Natural occurrence of nucleopolyhedrovirus infecting fall armyworm, Spodoptera frugiperda (J. E. Smith) (Lepidoptera: Noctuidae) in Gujarat, India. J Entomol Zool Stud 7(2):1040-1043 
Rakshit S, Ballal CR, Prasad YG, Sekhar JC, Lakshmi Soujanya P, Suby SB, Jat SL, Siva Kumar G, Prasad JV (2019) Fight against fall armyworm Spodoptera frugiperda (J. E. Smith). ICAR-Indian Institute of Maize Research, Ludhiana, Punjab, p 52

Roopika M, Srinivasan G, Shanthi M, Moorthy AV, Prabhu R (2020) First record on barnyard millet as a new host for fall armyworm, Spodoptera frugiperda (J. E. Smith) (Lepidoptera: Noctuidae) using novel insecticides and their residues on maize foliage. Paper presented in International seminar on Transboundry Pest Management March 4-5 2020, TNAU, Coimbatore, Tamil Nadu, India, p 45

Rwomushana I, Bateman M, Beale T, Beseh P, Cameron K, Chiluba M, Clottey V, Davis T, Day R, Early R, Godwin J, Gonzalez-Moreno P, Kansiime M, Kenis M, Makale F, Mugambi I, Murphy S, Nunda W, Phiri N, Pratt C, Tambo J (2018 ) Fall armyworm: impacts and implications for Africa Evidence Note Update : 1-53

Shanthi M, Srinivasan G, Nivetha TK, Gurusamy A (2020) First report on sugarbeet, as a new host for fall armyworm, Spodoptera frugiperda (J. E. Smith) (Lepidoptera: Noctuidae) in Madhurai, Tamil Nadu. Paper presented in International Seminar on Transboundry Pest Management March 4-5 2020, TNAU, Coimbatore, Tamil Nadu, India, p 43

Sharanabasappa D, Kalleshwaraswamy CM, Asokan R, Mahadeva Swamy HM, Maruthi MS, Pavithra HB, Hegde K, Navi S, Prabhu ST, Goergen G (2018a) First report of the fall armyworm, Spodoptera frugiperda (J E Smith) (Lepidoptera, Noctuidae), an alien invasive pest on maize in India. Pest Manag Hort Ecosyst 24:23-29

Sharanabasappa D, Kalleshwaraswamy CM, Maruthi MS, Pavithra HB (2018b) Biology of invasive fall army worm Spodoptera frugiperda(J.E. smith) (Lepidoptera: Noctuidae) on maize. Indian J Entomol 80(3):540-543

Sharanabasappa D, Kalleshwaraswamy CM, Poorani J, Maruthi MS, Pavithra HB, Diraviam J (2019a) Natural enemies of Spodoptera frugiperda (J. E. Smith) (Lepidoptera: Noctuidae), a recent invasive pest on maize in South India. Fla Entomol 1029(2):619-623

Sharanabasappa D, Kalleshwaraswamy CM, Shivanna BK, Hosamani Arunkumar C, Jagdish Jaba, Hanchinal SG (2019b) Fall armyworm, Spodoptera frugiperda(J E Smith): incidence, host range and its management. Paper presented in XIX International Plant Protection Congress IPPC 2019, November 10-14, 2019. Hyderabad, Telangana, India

Sharanabasappa D, Kalleshwaraswamy CM, Kiran S, Shivanna BK, Mathapati SC, Hareesh S (2020a) Invasive fall Armyworm, Spodoptera frugiperda and its management in maize. Research Bulletin Published by the University of Agricultural and Horticultural Sciences, Shivamogga pp12

Sharanabasappa D, Pavithra HB, Kalleshwaraswamy CM, Shivanna BK, Maruthi MS, MotaSanchez D (2020b) Field efficacy of insecticides for control of invasive fall armyworm, Spodoptera frugiperda(J. E. Smith) (Lepidoptera: Noctuidae) on maize in India. Fla Entomol 103(2):221-227

Shylesha AN, Sravika A (2018) Natural occurrence of predatory bugs, Eocanthecona furcellata (Wolff) and Andrallus spinidens (Fabr.) on Spodoptera frugiperda (Smith) (Hemiptera : Pentatomidae) in maize and their potential in management of fall army worm. J Biol Control 32(3):209-211

Shylesha AN, Jalali SK, Gupta A, Varshney R, Venkatesan T, Shetty P, Ojha R, Ganiger PC, Navik O, Subaharan K, Bakthavatsalam N, Ballal CR (2018) Studies on new invasive pest Spodoptera frugiperda (J. E. Smith) (Lepidoptera: Noctuidae) and its natural enemies. J Biol Control 32(3): 1-7

Silva-Brandao KL, Horikoshi R-J, Bernordi D, Omoto C, Figueira A, Brandap MM (2017) Transcript expression plasticity as a response to alternative larval host plants in the speciation process of corn and rice strains of Spodoptera frugiperda. BMC Genomics 18:792. https://doi. org/10.1186/s12864-017-4170-z

Sisay B, Simiyu J, Malusi P, Likhayo P, Mendesil E, Elibariki N, Wakgari M, Ayalew G, Tefera T (2018) First report of the fall armyworm, Spodoptera frugiperda (Lepidoptera: Noctuidae), natural enemies from Africa. J Appl Entomol 142(8):800-804 
Sisay B, Tadele T, Mulatu W, Gashawbeza A, Esayas M (2019) The efficacy of selected synthetic insecticides and botanicals against fall armyworm, Spodoptera frugiperda, in maize. Insects 10 (2). https://doi.org/10.3390/insects10020045

Sparks AN (1979) Review of the biology of the fall armyworm. Fla Entomol 62(2):82-87

Srikanth J, Geetha N, Singaravelu B, Ramasubramanian T, Mahesh P, Saravanan L, Salin KP, Chitra N, Muthukumar M (2018) First report of occurrence of fall armyworm, Spodoptera frugiperda in sugarcane from Tamil Nadu, India. J Sugarcane Res 8(2):195-202

Venkateswarlu U, Johnson M, Narasimhulu R, Muralikrishna T (2018) Occurrence of the fall armyworm, Spodoptera frugiperda (J. E. Smith) (Lepidoptera, Noctuidae), a new pest on bajra and sorghum in the fields of agricultural research station, Ananthapuramu, Andhra Pradesh, India. J Entomol Zool Stud 6(6):811-813

Wild S (2017) African countries mobilize to battle invasive caterpillar. Nature 543, 13-14.

Wilson EO (1992) The diversity of life. Harvard University Press, Cambridge, p 464

Wyckhuys KAG, O’Neil RJ (2006) Population dynamics of Spodoptera frugiperda Smith (Lepidoptera: Noctuidae) and associated arthropod natural enemies in Honduran subsistence maize. Crop Prot 25:1180-1190

Yu SJ (1991) Insecticide resistance in the fall armyworm, Spodoptera frugiperda (J. E. Smith). Pest Biochem Physiol 39(1):84-91 